\title{
Formulasi dan Uji Karakteristik SNEDDS Asiklovir
}

\section{Nanda Dwi Akbar ${ }^{1}$, Akhmad Kharis Nugroho2*, Sudibyo Martono ${ }^{3}$}

${ }^{1}$ Magister IImu Farmasi, Fakultas Farmasi, Universitas Gadjah Mada Sekip Utara, 55281, Yogyakarta, Indonesia

2Departemen Farmasetika, Fakultas Farmasi, Universitas Gadjah Mada, Sekip Utara, 55281,

Yogyakarta, Indonesia

${ }^{3}$ Departemen Kimia Farmasi, Fakultas Farmasi, Universitas Gadjah Mada, Sekip Utara, 55281,

Yogyakarta, Indonesia

*E-mail: a.k.nugroho@ugm.ac.id

(Submit 30/09 /2021, Revisi 22/10/2021, Diterima 26/11/2021, Terbit 10/12/2021)

\begin{abstract}
Abstrak
Asiklovir termasuk ke dalam biopharmaceuticals classification system (BCS) kelas III. Obat yang tergolong ke dalam BCS kelas III memiliki kelarutan tinggi dan permeabilitas rendah. SNEDDS terbukti dapat meningkatkan kelarutan, disolusi dan permeabilitas obat. Tujuan penelitian ini adalah mengembangkan formulasi SNEDDS asiklovir yang berpotensi untuk peningkatan perrmeabilitas asiklovir. Asam oleat, chremophor RH 40 dan transcutol masing-masing dipilih sebagai minyak, surfaktan dan ko-surfaktan. Sebelum dilakukan pembuatan formulasi SNEDDS asiklovir, dilakukan uji kelarutan asiklovir dalam transcutol HP dan optimasi basis SNEDDS tanpa asiklovir. Uji karakteristik SNEDDS asiklovir meliputi waktu emulsifikasi, visual, ukuran droplet dan indeks polidispersitas. Formulasi SNEDDS dengan perbandingan asam oleat-S $S_{\text {mix }}=1: 9$ dan perbandingan chremophor $\mathrm{RH}$ 40-transcutol HP = 3:1 menghasilkan nanoemulsi dengan visual transparan dengan waktu emulsifikasi, ukuran partikel dan indeks polidispersitas rata-rata masing-masing sebesar 12,667 \pm 0,577 detik, 14,803 \pm 4,07 $\mathrm{nm}$ dan 0,310 $\pm 0,104$. Formula SNEDDS asiklovir dengan perbandingan asam oleat$\mathrm{S}_{\text {mix }}=1: 9$ dan perbandingan chremophor $\mathrm{RH}$ 40-transcutol $\mathrm{HP}=3: 1$ merupakan formulasi SNEDDS asiklovir terbaik yang mememenuhi persyaratan visual, waktu emulsifikasi, ukuran partikel dan indeks polidispersitas.
\end{abstract}

Kata kunci: asiklovir, formulasi, karakteristik, SNEDDS

\section{Pendahuluan}

Asiklovir merupakan antivirus yang digunakan untuk pengobatan virus herpes simplex tipe I/II dan varicella zoster. Asiklovir termasuk ke dalam biopharmaceuticals classification system (BCS) kelas III(1). Obat yang tergolong ke dalam BCS kelas III memiliki kelarutan tinggi, namun memiliki permeabilitas yang rendah(2). Asiklovir memiliki nilai log $P$ (oktanol-air) sebesar -1,56 ${ }^{(3)}$. SNEDDS (self-nanoemulsifying drug delivery system) merupakan salah satu cara untuk meningkatkan permeabilitas obat. SNEDDS merupakan campuran isotropik yang terdiri dari obat, surfaktan, ko-surfaktan dan minyak. 
Beberapa penelitian telah membuktikan SNEDDS terbukti dapat meningkatkan kelarutan, disolusi dan permeabilitas obat ${ }^{(4)(5)(6)(7)(8)}$. Cairan dan motilitas lambung membantu SNEDDS menjadi nanoemulsi tipe minyak dalam air $(\mathrm{M} / \mathrm{O})^{(9)}$. Nanoemulsi biasanya memiliki ukuran droplet berkisar 20-200 $\mathrm{nm}^{(10)}$. Formulasi SNEDDS dapat meningkatkan absorpsi dan permeasi obat dengan membentuk droplet yang berukuran kurang dari $200 \mathrm{~nm}^{(9)}$. Tujuan penelitian ini yaitu mengembangkan formulasi SNEDDS asiklovir yang berpotensi untuk peningkatan perrmeabilitas asiklovir. Penelitian ini merupakan pengembangan dari penelitian sebelumnya tentang optimasi formulasi SMEDDS yang mengandung asiklovir, asam oleat, tween 80 dan transcutol $\mathrm{HP}^{(9)}$.

\section{Metode}

\section{Alat}

Instrumen yang digunakan dalam penelitian ini meliputi particle size analyzer (Malvern, United Kingdom), magnetic stirrer (IKA C-MAG HS7, Malaysia), sonikator (Selecta, Francis), spektrofotometer UV-Vis (Genesys, United States), timbangan neraca analitik (Mettler Toledo, Switzerland), pH meter (Hanna, Romania) dan waterbath (Selecta, Francis).

\section{Bahan}

Bahan yang digunakan dalam penelitian ini meliputi asiklovir (PT.Pharos), asam oleat (Brataco), chremophor $\mathrm{RH} 40$ (BASF), $\mathrm{NaCl}$ (Universitas Gadjah Mada), $\mathrm{KH}_{2} \mathrm{PO}_{4}$ (Universitas Gadjah Mada), $\mathrm{Na}_{2} \mathrm{HPO}_{4} \cdot 2 \mathrm{H}_{2} \mathrm{O}$ (Universitas Gadjah Mada), $\mathrm{KCl}$ (Universitas Gadjah Mada), $\mathrm{HCl} 1 \mathrm{~N}$ (Universitas Gadjah Mada), transcutol HP (PT.Pharos), akuades (Genera Labora) dan water for injection (Genera Labora).

\section{Prosedur}

1. Pembuatan Buffer Posfat $\mathrm{pH} 7,4$

Pembuatan buffer posfat $\mathrm{pH} 7,4$ dilakukan dengan menimbang $\pm 8 \mathrm{~g} \mathrm{NaCl}, 245 \mathrm{mg}$ $\mathrm{KH}_{2} \mathrm{PO}_{4}, 1,44 \mathrm{~g} \mathrm{Na}_{2} \mathrm{HPO}_{4} .2 \mathrm{H}_{2} \mathrm{O}$ dan $200 \mathrm{mg} \mathrm{KCl}$, kemudian dilarutkan akuades hingga $800 \mathrm{~mL}$. Nilai $\mathrm{pH}$ larutan yang terlalu basa diadjust dengan $\mathrm{HCl} 1 \mathrm{~N}$, kemudian diukur dengan $\mathrm{pH}$ meter (Hanna, Romania).

2. Uji Kelarutan Asiklovir dalam Transcutol HP

Sebanyak 3 vial masing-masing dimasukkan $\pm 2 \mathrm{~g}$ transcutol HP. Asiklovir ditimbang $\pm 30 \mathrm{mg}$ dan dimasukkan ke dalam vial. Campuran diaduk dengan stirrer pada kecepatan $300 \mathrm{rpm}$ selama 10 menit. Campuran disonikasi selama 15 menit ${ }^{(11)}$. Setiap vial didiamkan masing-masing selama 22, 23 dan 24 jam. Campuran disentrifugasi pada kecepatan 4000 rpm selama 10 menit. Sebanyak 30 $\mu \mathrm{L}$ supernatan dipipet ke dalam labu ukur $10 \mathrm{~mL}$ dan diencerkan dengan dapar posfat $\mathrm{pH} 7,4$ hingga $10 \mathrm{~mL}$. Absorban diukur dengan spektrofotometer (Genesys, United States) pada $\lambda=250 \mathrm{~nm}$ terhadap blanko.. 


\section{Optimasi Basis SNEDDS}

Perbandingan asam oleat dan $\mathrm{S}_{\text {mix }}$ (campuran chremophor $\mathrm{RH} 40$ dan transcutol HP) adalah 1:9, 1:8, 1:7, 1:6, 1:5, 1:4, 1:3, 1:2 dan 1:1. Perbandingan chremophor $\mathrm{RH} 40$ dan transcutol HP adalah 3:1. Asam oleat, chremophor RH 40 dan transcutol HP ditimbang kurang lebih sesuai dengan jumlah yang ditentukan dan dicampur dalam satu vial. Campuran dipanaskan pada suhu $40^{\circ} \mathrm{C}$ selama 10 menit. Campuran diaduk dengan stirrer pada kecepatan 300 rpm selama 10 menit. Campuran disonikasi selama 10 menit. Visual basis SNEDDS diamati pada kondisi awal dan setelah 24 jam. Basis SNEDDS yang telah disimpan selama 24 jam, kemudian diemulsifikasikan dengan water for injection dan dilakukan pengukuran ukuran droplet menggunakan particle size analyzer.

\section{Pembuatan SNEDDS Asiklovir}

Asam oleat, chremophor RH 40 dan transcutol HP ditimbang kurang lebih sesuai dengan jumlah yang ditentukan dan dicampur dalam satu vial. Campuran dipanaskan pada suhu $40^{\circ} \mathrm{C}$ selama 10 menit. Campuran dihomogenkan dengan stirrer pada kecepatan 300 rpm selama 10 menit dan disonikasi selama 10 menit. Asiklovir ditimbang akurat $10,0 \mathrm{mg}$ dan ditambahkan ke dalam basis SNEDDS dan diaduk dengan stirrer pada kecepatan 300 rpm selama 10 menit. Campuran disonikasi selama 30 menit.

\section{Evaluasi}

a. Waktu Emulsifikasi dan Visual

Sebanyak $100 \mu \mathrm{L}$ SNEDDS dipipet ke dalam beaker glass berisi $10 \mathrm{~mL}$ water for injection pada suhu $37^{\circ} \mathrm{C}$. Campuran diaduk dengan stirrer pada kecepatan 100 rpm. Waktu emulsifikasi dihitung ketika SNEDDS kontak dengan water for injection hingga teremulsifikasi seluruhnya. Visual setiap formulasi SNEDDS teremulsifikasi diamati.

b. Pengukuran Ukuran Droplet

Pengukuran ukuran droplet dilakukan pada SNEDDS yang sudah teremulsifikasi seluruhnya oleh water for injection. Campuran diletakkan dalam kuvet gelas dan dimasukkan ke dalam particle size analyzer. Pengukuran ukuran partikel dilakukan pada suhu $25^{\circ} \mathrm{C}$ dan sudut $90^{\circ}(12)$. Pembacaan dilakukan sebanyak 3 kali.

c. Pengukuran Indeks Polidispersitas

Pengukuran indeks polidispersitas dilakukan pada SNEDDS yang sudah teremulsifikasi seluruhnya oleh water for injection. Campuran diletakkan dalam kuvet gelas dan dimasukkan ke dalam particle size analyzer. Pengukuran ukuran partikel dilakukan pada suhu $25^{\circ} \mathrm{C}$ dan sudut $90^{\circ(12)}$. Pembacaan dilakukan sebanyak 3 kali. 


\section{Hasil}

Kelarutan Asiklovir dalam Transcutol HP

Asiklovir memiliki kelarutan dalam transcutol HP sebesar 2,139 $\pm 0,174 \mathrm{mg} / \mathrm{mL}$.

\section{Optimasi Basis SNEDDS}

Semua formula basis SNEDDS stabil selama penyimpanan 24 jam dengan visual transparan sebelum teremulsifikasi. Formula basis SNEDDS dengan perbandingan asam oleat dan $S_{\text {mix }}$ yaitu 1:9, 1:8 dan 1:7, memiliki visual transparan dengan ukuran droplet masing-masing sebesar 12,51, 14,61 dan $56,31 \mathrm{~nm}$, sedangkan formulasi basis SNEDDS lainnya mengalami kekeruhan setelah teremulsifikasi dengan ukuran droplet lebih dari $100 \mathrm{~nm}$. Basis SNEDDS untuk asiklovir dipilih dengan perbandingan asam oleat dan $\mathrm{S}_{\text {mix }}$ (chremophor RH 40 dan transcutol HP) adalah 1:9. Visual dan ukuran droplet basis SNEDDS teremulsifikasi tertera pada Tabel 1.

Waktu Emulsifikasi dan Visual

SNEDDS asiklovir memiliki waktu emulsifikasi rata-rata sebesar 12,667 $\pm 0,577$ detik. SNEDDS menghasilkan nanoemulsi dengan visual transparan setelah teremulsifikasi dalam water for injection. Visual SNEDDS dan nanoemulsi asiklovir dapat dilihat pada Gambar 1.

\section{Ukuran Droplet}

SNEDDS asiklovir memiliki ukuran droplet rata-rata sebesar 14,803 $\pm 4,07 \mathrm{~nm}$ ketika teremulsifikasikan dalam water for injection. Ukuran droplet SNEDDS asikovir dapat dilihat pada Gambar 2.

Indeks Polidispersitas

SNEDDS asiklovir memiliki indeks polidispersitas rata-rata sebesar 0,310 $\pm 0,104$. Indeks polidispersitas SNEDDS asikovir dapat dilihat pada Gambar 2. 
Tabel 1 Visual dan ukuran droplet Basis SNEDDS teremulsifikasi

\begin{tabular}{|c|c|c|c|c|}
\hline Formula & $\begin{array}{c}\text { Asam } \\
\text { Oleat:S } \\
\text { mix }\end{array}$ & $\begin{array}{l}\text { Chremophor RH } \\
\text { 40:Transcutol HP }\end{array}$ & Visual & $\begin{array}{c}\text { Ukuran } \\
\text { Droplet } \\
(\mathrm{nm}) \\
\end{array}$ \\
\hline 1 & $1: 9$ & & $\begin{array}{ll}\text { Transparan } & \text { dan } \\
\text { tidak berwarna } & \\
\text { Transparan } & \text { dan }\end{array}$ & 12,51 \\
\hline 2 & $1: 8$ & & $\begin{array}{l}\text { tidak berwarna } \\
\text { Transparan dan }\end{array}$ & 14,61 \\
\hline 3 & $1: 7$ & & $\begin{array}{l}\text { tidak berwarna } \\
\text { Agak keruh }\end{array}$ & 56,31 \\
\hline 4 & $1: 6$ & $3: 1$ & $\begin{array}{l}\text { berwarna putih } \\
\text { Agak keruh }\end{array}$ & 182,4 \\
\hline 5 & $1: 5$ & & $\begin{array}{l}\text { berwarna putih } \\
\text { Agak keruh }\end{array}$ & 249,1 \\
\hline 6 & 1:4 & & $\begin{array}{l}\text { berwarna putih } \\
\text { Keruh berwarna }\end{array}$ & 261,2 \\
\hline 7 & $1: 3$ & & putih & 194,7 \\
\hline 8 & $1: 2$ & & Pemisahan & 201,5 \\
\hline 9 & $1: 1$ & & Pemisahan & 176,6 \\
\hline
\end{tabular}

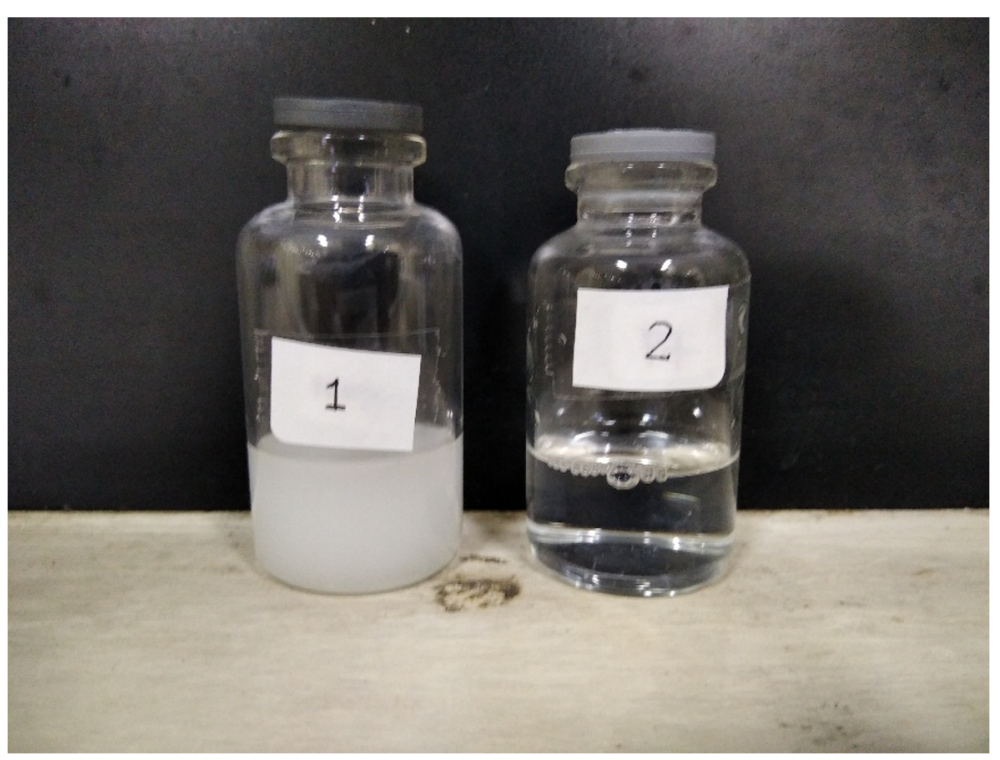

Gambar 1 Visual SNEDDS (1) dan nanoemulsi asiklovir (2) 


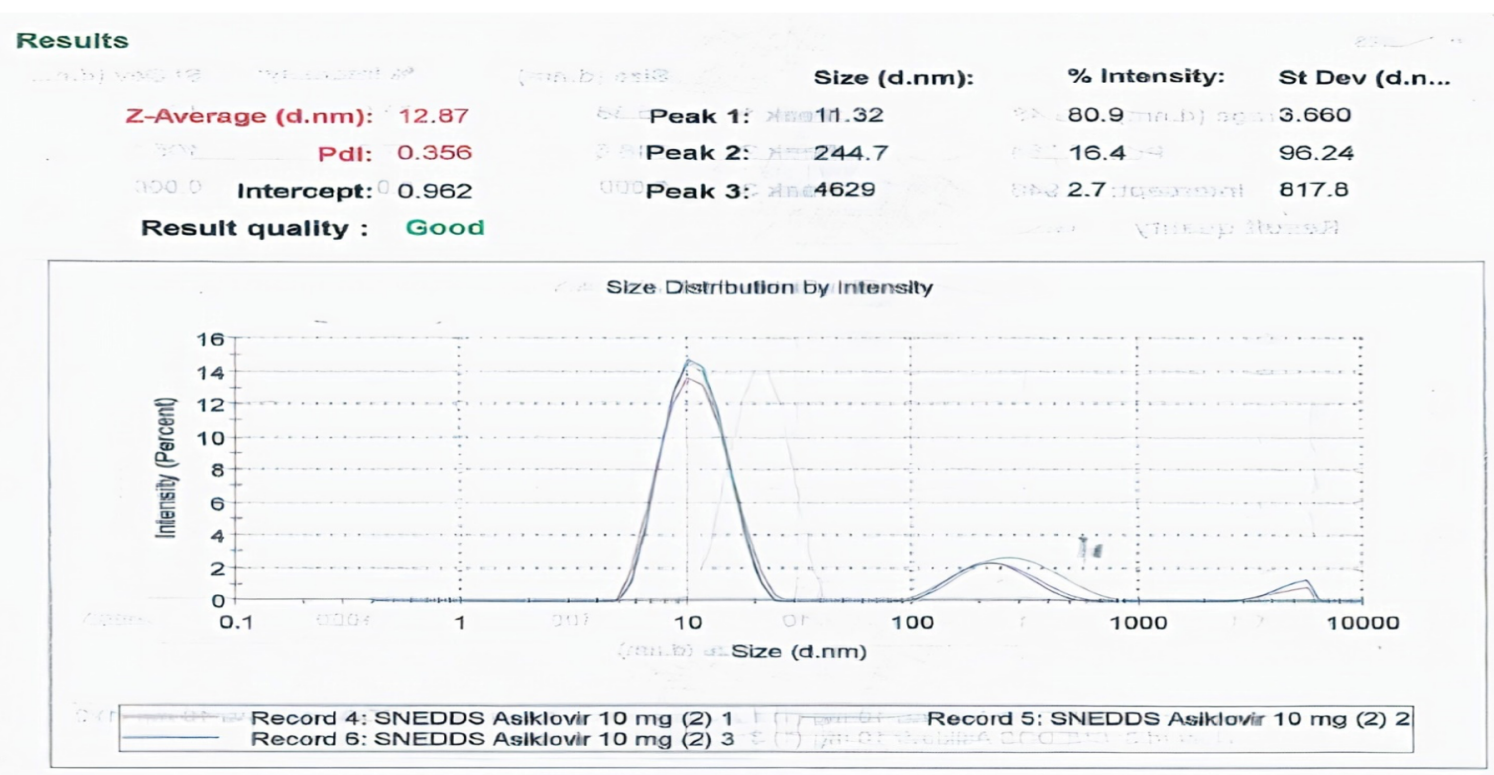

Gambar 2 Ukuran droplet dan indeks polidispersitas SNEDDS asiklovir teremulsifikasi

\section{Pembahasan}

\section{Uji Kelarutan Asiklovir dalam Transcutol HP}

Uji kelarutan dilakukan untuk memprediksikan jumlah maksimal asiklovir yang dapat larut dalam transcutol HP. Asiklovir yang dicampurkan ke dalam transcutol HP menghasilkan larutan jenuh karena asiklovir mencapai kelarutan maksimal dalam transcutol HP. Sonikasi dapat menghomogenkan dan meningkatkan jumlah zat terlarut dalam pembawa ${ }^{(9)}$. Sonikator dilakukan untuk memaksimalkan jumlah asiklovir terlarut dalam keadaan maksimal. Sentrifugasi dilakukan untuk memisahkan endapan asiklovir yang tidak terlarut. Panjang gelombang maksimal UV dipilih $250 \mathrm{~nm}$ karena larutan asiklovir dalam buffer posfat $\mathrm{pH} 7,4$ menghasilkan absorbansi maksimal pada $\lambda_{\max } 250$ $\mathrm{nm}$. Berdasarkan literatur sebelumnya, nlai $\lambda_{\max }$ larutan asiklovir dalam air adalah 252 $\mathrm{nm}^{(20)}$. Nilai $\lambda_{\max }$ larutan asiklovir antara dalam bufer posfat $\mathrm{pH} 7,4$ dan air tidak begitu jauh berbeda.

\section{Optimasi Basis SNEDDS}

Optimasi basis SNEDDS dilakukan untuk mendapatkan basis SNEDDS yang memiliki kriteria berupa visual transparan, ukuran droplet kurang dari $200 \mathrm{~nm}$ dan stabil selama penyimpanan. Pemananasan berfungsi untuk menurunkan viskositas campuran sehingga mudah untuk diaduk dengan stirrer bersama dengan asiklovir. Sonikasi dapat menghomogenkan dan meningkatkan jumlah zat terlarut dalam pembawa ${ }^{(14)}$. Asiklovir yang dicampur dengan basis SNEDDS dan disonikasi selama 10 menit menyebabkan campuran menjadi homogen. Hasil pengukuran ukuran droplet, 3 formula memiliki visual transparan setelah teremulsifikasi, 
stabil selama penyimpanan dan ukuran droplet kurang dari $200 \mathrm{~nm}$ yaitu formula SNEDDS dengan perbandingan asam oleat dan $S_{\text {mix }}$ sebesar 1:9, 1:8 dan 1:7. Peningkatan jumlah chremophor $\mathrm{RH} 40$ menunjukkan pengecilan ukuran partikel. Berdasarkan literatur, perbandingan chremophor $\mathrm{RH} 40$ dan transcutol HP dalam formulasi SNEDDS adalah 2:1(13). Asiklovir memiliki nilai log $\mathrm{P}$ (oktanol-air) sebesar 1,56 sehingga bersifat hidrofil. Peningkatan rasio chremophor $\mathrm{RH} 40$ dan transcutol HP menjadi 3:1 bertujuan untuk meningkatkan kelarutan asiklovir dalam SNEDDS. Hal ini dibuktikan dengan basis SNEDDS terpilih (asam oleat: $S_{\text {mix }}=1: 9$ ) yang stabil selama penyimpanan 24 jam tanpa terjadi pembentukan endapan dan pemisahan setelah ditambahkan asiklovir. Dosis asiklovir yang dicampurkan ke dalam basis SNEDDS terpilih (drug loading) adalah 10,0 mg karena menghasilkan SNEDDS yang stabil selama penyimpanan 24 jam dengan visual opaq. Peningkatan dosis hingga 40,0 mg menghasilkan SNEDDS dengan visual berwarna putih susu yang berpotensi terjadinya pengendapan asiklovir meskipun selama penyimpanan 24 jam, SNEDDS tidak mengalami pemisahan. SNEDDS memiliki karakteristik berupa visual transparan dengan ukuran droplet kurang dari $200 \mathrm{~nm}$ ketika teremulsifikasikan ${ }^{(9)(15)}$. Ukuran droplet basis SNEDDS teremulsifikasi paling kecil terdapat pada formula basis SNEEDS dengan perbandingan asam oleat dan $S_{\text {mix }}$ adalah 1:9 dengan ukuran droplet sebesar $12,51 \mathrm{~nm}$. Pemilihan asam oleat sebagai basis minyak karena asiklovir memiliki kelarutan dalam asam oleat sebesar $19,66 \mathrm{mg} / \mathrm{mL}^{(16)}$. Surfaktan dapat menghasilkan nanoemulsi tipe minyak dalam air apabila memiliki HLB lebih besar dari $10^{(15)}$. Surfaktan yang terlokalisasi pada droplet emulsi dapat menurunkan energi bebas antar muka dan menghasilkan barier terhadap koalesensi sehingga terjadi dispersi spontan secara termodinamika. Pemilihan chremophor $\mathrm{RH} 40$ sebagai sebagai surfaktan karena chremophor RH 40 merupakan surfaktan non-ionik yang memiliki HLB 14-16 dan stabilitas yang baik dalam air ${ }^{17)(18)}$. Transcutol HP berperan sebagai kosurfaktan yang berfungsi untuk meningkatkan dipersibilitas dan absorpsi dalam formulasi ${ }^{(19)}$. Kombinasi penggunaan chremophor $\mathrm{RH} 40$ dan transcutol HP dapat meningkatkan kelarutan asiklovir dalam SNEDDS secara merata melalui mekanisme penurunan energi bebas yang dapat menurunkan tegangan antar muka antara asiklovir dan basis SNEDDS.

\section{Pembuatan SNEDDS Asiklovir}

Pembuatan SNEDDS asiklovir dibedakan menjadi dua metode yaitu metode energi rendah dan energi tinggi. Metode emulsifikasi termasuk ke dalam metode pembuatan nanoemulsi dengan metode energi rendah, sedangkan sonikasi merupakan pembuatan nanoemulsi dengan metode energi tinggi. (21). Pemanasan dilakukan untuk menurunkan viskositas chremophor $\mathrm{RH} 40$ sehingga mudah dicampurkan dengan asam oleat dan transcutol HP ketika diaduk dengan stirrer. Pemanasan dapat menurunkan viskositas pembawa yang memfasilitasi terlarutnya zat ${ }^{(11)}$. Chremophor $\mathrm{RH} 40$ memiliki viskositas yang lebih kental dari pada asam oleat dan transcutol HP. Pengadukan asam oleat, chremophor RH 40 dan transcutol HP dengan stirrer menghasilkan basis SNEDDS yang homogen. Penambahan asiklovir ke dalam basis SNEDDS menghasilkan endapan asiklovir dalam basis SNEDDS sehingga dilakukan sonikasi untuk melarutkan asiklovir dalam basis SNEDDS. 
Waktu Emulsifikasi dan Visual

Waktu emulsifikasi menunjukkan seberapa cepat suatu SNEDDS teremulsifikasi dalam air ketika teraduk perlahan ${ }^{(19)}$. SNEDDS teremulsifkasi menghasilkan SNEDDS dengan visual transparan, stabil dan memiliki waktu emulsifikasi kurang dari 1 menit. Formulasi SNEDDS memiliki waktu emulsifikasi kurang dari 1 menit menunjukkan SNEDDS menghasilkan nanoemulsi yang baik ${ }^{(22)}$. Karakter SNEDDS yang stabil yaitu SNEDDS tidak mengalami pemisahan, presipitasi, koalesensi dan konversi menjadi emulsi ${ }^{(23)}$.

\section{Ukuran Droplet}

Setiap SNEDDS asiklovir teremulsifikasi memiliki ukuran droplet kurang dari $200 \mathrm{~nm}$. Salah satu karakteristik SNEDDS adalah ukuran droplet kurang dari $200 \mathrm{~nm}$ ketika teremulsifikasi. Peningkatan rasio minyak dan surfaktan menciptakan sistem yang stabil sehingga mendukung penurunan ukuran partikel ketika dalam bentuk nanoemulsi(24). Surfaktan menurunkan tegangan permukaan dan antar muka seiring dengan penambahan konsentrasi surfaktan ${ }^{(25)}$. Penurunan tegangan antar muka menyebabkan penurunan energi bebas Gibbs sehingga menyebabkan penurunan ukuran partikel(26). Faktor-faktor lain yang mempengaruhi ukuran partikel antara lain pengadukan, efek surfaktan dan viskositas relatif diantara fase terdispersi dan fase pendispersi(27). Ukuran droplet SNEDDS asiklovir yang relatif kecil disebabkan efek chremophor $\mathrm{RH} 40$ terhadap penurunan tegangan antar muka antara air dengan SNEDDS yang berakibat pada penurunan energi bebas Gibbs.

\section{Indeks Polidispersitas}

Indeks polidispersitas merupakan ukuran keseragaman ukuran diameter partikel(28). Nilai indeks polidispersitas kurang dari 0,2 menunjukkan distribusi ukuran partikel yang sempit, seragam dan monodispersi(28)(29). Semakin kecil nilai indeks polidispersitas menunjukkan semakin seragam ukuran partikel. Persyaratan nilai indeks polidispersitas untuk sediaan nanopartikel adalah kurang dari $0,5^{(30)}$. Nilai indeks polidispersitas mendekati 1 menunjukkan sistem polidispersi(28). SNEDDS asiklovir memiliki ukuran partikel yang seragam.

\section{Kesimpulan}

Formula SNEDDS asiklovir dengan perbandingan asam oleat- $S_{\text {mix }}$ adalah 1:9 dan perbandingan chremophor RH 40 -transcutol HP adalah 3:1 merupakan formulasi SNEDDS asiklovir terbaik yang memenuhi persyaratan visual, waktu emulsifikasi, ukuran droplet dan indeks polidispersitas.

\section{Daftar Pustaka}

1. Nair AB, Attimarad $M$, Al-Dhubiab BE, Wadhwa J, Harsha $S$, Ahmed $M$. Enhanced oral bioavailability of acyclovir by inclusion complex using hydroxypropyl- $\beta$-cyclodextrin. Drug Deliv. 2014;21(7):540-7. 
2. Parr A, Hidalgo IJ, Bode C, Brown W, Yazdanian M, Gonzalez MA, et al. The Effect of Excipients on the Permeability of BCS Class III Compounds and Implications for Biowaivers. Pharm Res. 2016;33(1):167-76.

3. Moffat AC, Osselton MD, Widdop B. Clarke's Analysis Drugs and Poisons. Fourth Edition. London: Pharmaceutical Press; 2011.

4. Priani SE, Annisa A, Darma GCE. Dissolution enhancement of atorvastatin calcium by self-nanoemulsifying drug delivery system using cremophor RH 40 and Transcutol P as surfactants. Drug Invent Today. 2018;10(5):3768-72.

5. Astuti IY, Marchaban, Martien R, Nugroho AE. Physical characterization and dissolution study of pentagamavunon-0 loaded self nano-emulsifying drug delivery system. Indones J Pharm. 2018;29(2):60-5.

6. Singh G, Pai RS. Trans-resveratrol self-nano-emulsifying drug delivery system (SNEDDS) with enhanced bioavailability potential: Optimization, pharmacokinetics and in situ single pass intestinal perfusion (SPIP) studies. Drug Deliv. 2015;22(4):522-30.

7. Kazi M, Al-Swairi M, Ahmad A, Raish M, Alanazi FK, Badran MM, et al. Evaluation of self-nanoemulsifying drug delivery systems (SNEDDS) for poorly water-soluble talinolol: Preparation, in vitroand in vivoAssessment. Front Pharmacol. 2019;10:1-13.

8. Karavasili C, Andreadis II, Tsantarliotou MP, Taitzoglou IA, Chatzopoulou P, Katsantonis D, et al. Self-Nanoemulsifying Drug Delivery Systems (SNEDDS) Containing Rice Bran Oil for Enhanced Fenofibrate Oral Delivery: In Vitro Digestion, Ex Vivo Permeability, and In Vivo Bioavailability Studies. AAPS PharmSciTech. 2020;21(208):1-10.

9. Ghai D, Sinha VR. Nanoemulsions as self-emulsified drug delivery carriers for enhanced permeability of the poorly water-soluble selective $\beta 1$-adrenoreceptor blocker Talinolol. Nanomedicine Nanotechnology, Biol Med. 2012;8(5):618-26.

10. Jaiswal M, Dudhe R, Sharma PK. Nanoemulsion: an advanced mode of drug delivery system. 3 Biotech. 2015;5(2):123-7.

11. Astuti I., Marchaban, Martien R, Nugroho A. Formulation of Self Nano-emulsifying Drug Delivery System Pentagamavunon-0 as a Candidate for Inflammatory Therapy. Proceeding of The $1^{\text {st }}$ University of Muhammadiyah Purwokerto Pharmacy International Conference 2015; 2015 June 5-6. Purwokerto, Indonesia: Horison Hotel Purwokerto:150-155.

12. Indrati $\mathrm{O}$, Martien R, Rohman A, Nugroho AK. Application of simplex lattice design on the optimization of andrographolide self nanoemulsifying drug delivery system (SNEDDS). Indones J Pharm. 2020;31(2):124-30.

13. Mahmoud $H$. Design and optimization of self-nanoemulsifying drug delivery systems of simvastatin aiming dissolution enhancement. African $\mathrm{J}$ Pharm Pharmacol. 2013;7(22):1482-500.

14. Pereira SV, Colombo FB, De Freitas LAP. Ultrasound influence on the solubility of solid dispersions prepared for a poorly soluble drug. Ultrason Sonochem. 2016;29:461-9. 
15. Kassem AA, Mohsen AM, Ahmed RS, Essam TM. Self-nanoemulsifying drug delivery system (SNEDDS) with enhanced solubilization of nystatin for treatment of oral candidiasis: Design, optimization, in vitro and in vivo evaluation. J Mol Liq. 2016;218:219-32.

16. Puttachari S, Kalyane N V., Sarbaniduttagupta. Design and evaluation of selfmicro emulsifying drug delivery systems of Acyclovir. Int J Pharm Pharm Sci. 2014;6(4):677-81.

17. Larsen AT, Ogbonna A, Abu-Rmaileh R, Abrahamsson B, Østergaard J, Müllertz A. SNEDDS containing poorly water soluble cinnarizine; development and In vitro characterization of dispersion, digestion and solubilization. Pharmaceutics. 2012;4(4):641-65.

18. Fitria A, Hanifah S, Chabib L, Uno AM, Munawwarah $\mathrm{H}$, Atsil N, et al. Design and characterization of propolis extract loaded self-nano emulsifying drug delivery system as immunostimulant. Saudi Pharm J. 2021;29(6):625-34.

19. Patel J, Kevin G, Patel A, Raval M, Sheth N. Design and development of a selfnanoemulsifying drug delivery system for telmisartan for oral drug delivery. Int $\mathrm{J}$ Pharm Investig. 2011;1(2):112.

20. Dongare U, Chemate S, Jadhav S, Pawar V. Spectrophotometric Determination And Validation Of Acyclovir In Tablet Dosage Form. IntJPharmTech Res. 2012;4(4):1841-5.

21. Hidajat MJ, Jo W, Kim H, Noh J. Article effective droplet size reduction and excellent stability of limonene nanoemulsion formed by high-pressure homogenizer. Colloids and Interfaces. 2020;4(1).

22. Sunitha, MR, Sowjanya N. Formulation and in-vitro characterization of solid self nanoemulsifying drug delivery system (S-SNEDDS) of Simvastatin. J Pharm Sci Res. 2015;7(1):40-8.

23. Anwer MK, Iqbal M, Aldawsari MF, Alalaiwe A, Ahmed MM, Muharram MM, et al. Improved antimicrobial activity and oral bioavailability of delafloxacin by selfnanoemulsifying drug delivery system (SNEDDS). J Drug Deliv Sci Technol. 2021;64(102572):1-8.

24. Bravo-Alfaro DA, Muñoz-Correa MOF, Santos-Luna D, Toro-Vazquez JF, CanoSarmiento C, García-Varela R, et al. Encapsulation of an insulin-modified phosphatidylcholine complex in a self-nanoemulsifying drug delivery system (SNEDDS) for oral insulin delivery. J Drug Deliv Sci Technol. 2020;57(101622):17.

25. Adisalamun, Mangunwidjaja DM, Suryani A, Sunarti T., Arkeman Y. Optimasi proses produksi surfaktan nonionik alkil poliglikosida (apg) dengan metode permukaan respons. 2012;22(1):51-7.

26. Yoshida M, Kato $Y$, Oumi $Y$, Sakurada O, Tanaka M, Wada M, et al. Homogeneous nucleation of corundum nanocrystallites by rapid heating of aluminum formate hydroxide-based precursor powder. Sci Rep. 2019;9(1):2-4. 
27. Mahdi L, Sudibyo RS, Martien R. Self-nano emulsifying drug delivery system (SNEDDS) of curcuma mangga Val. essential oil and the stability study. Indones J Pharm. 2020;31(4):238-43.

28. Tubesha Z, Abu Bakar Z, Ismail M. Characterization and stability evaluation of thymoquinone nanoemulsions prepared by high-pressure homogenization. J Nanomater. 2013;2013.

29. Singh Y, Meher JG, Raval K, Khan FA, Chaurasia M, Jain NK, et al. Nanoemulsion: Concepts, development and applications in drug delivery. J Control Release. 2017;252:28-49.

30. Nurkhasanah. the development of chitosan nanoparticles sabdariffa $L$ calyx extract from indonesia and thailand. Int J Pharm Sci Res. 2015;6(5):1855-ar 